\title{
The role of the hydrodynamic regime in the distribution of the invasive shrub Baccharis halimifolia (Compositae) in Oyambre Estuary (Cantabria, Spain)
}

\author{
Diego Frau ${ }^{1, *}$, Bárbara Ondiviela Eizaguirre ${ }^{2}$, Cristina Galván Arbeiza ${ }^{2}$ \\ and José Antonio Juanes de la Peña ${ }^{2}$ \\ ${ }^{1}$ Plankton Department. Limnology National Institute (CONICET-UNL), Ciudad Universitaria, 3000 Santa Fe, \\ Argentina. \\ ${ }^{2}$ Environmental Hydraulics Institute "IH Cantabria", Universidad de Cantabria. C/ Isabel Torres $\mathrm{n}^{\circ}$ 15. Parque \\ Científico y Tecnológico de Cantabria. 39011, Santander, Spain \\ *Corresponding author: diegofrau@gmail.com
}

Received: 15/05/2013 Accepted: 10/10/2013

\begin{abstract}
The role of the hydrodynamic regime in the distribution of the invasive shrub Baccharis halimifolia (Compositae) in Oyambre Estuary (Cantabria, Spain)

Coastal estuaries are affected by an increasing number of human interventions, including the introduction of invasive species. Baccharis halimifolia is endemic to the east coast of North America and in recent decades has colonised a large number of estuaries in northern Spain. Although hydrodynamic conditions play an important role in the creation of niches for plant species in salt marshes, their interaction with the spatial distribution of $B$. halimifolia remains poorly studied. This study identified the main hydrodynamic variables controlling the distribution of this species in Oyambre estuary (Cantabria, Spain) and used these variables to model the habitat of the plant. B. halimifolia develops in areas that are inundated $<26 \%$ of the year, with salinity $<25 \mathrm{~g} / \mathrm{L}$, and water speed and water flow $<0.1 \mathrm{~m} / \mathrm{s}$ and $<0.85 \mathrm{~m}^{3} / \mathrm{s}$, respectively. Habitat suitability modelling showed that this plant is not equally represented throughout the estuary; preferring areas where hydrodynamic values are lower than average. The plant also showed medium tolerance to the present hydrodynamic conditions (tolerance $\ll 1$ ), preferring areas that are inundated 0 to $21 \%$ of the year, with salinity between 0 and $26 \mathrm{~g} / \mathrm{L}$. Changes in hydromorphologic conditions may have a predictable impact on the type and distribution of vegetation in salt marshes. B. halimifolia will remain in areas where tidal influence is reduced, competing with native vegetation.
\end{abstract}

Key words: Baccharis halimifolia, habitat suitability, hydrodynamic conditions, invasive species, salt marshes.

\section{RESUMEN}

El rol del régimen hidrodinámico en la distribución del arbusto invasor Baccharis halimifolia (Compositae) en el estuario de Oyambre (Cantabria, España)

Un número creciente de intervenciones humanas afectan los estuarios costeros, siendo la introducción de especies invasoras una de las más notables. Baccharis halimifolia es una planta nativa de la región costera este de Norte América, que en las últimas décadas ha colonizado un gran número de estuarios en el norte de España. Si bien las condiciones hidrodinámicas juegan un rol preponderante en la creación de nichos ecológicos para la vegetación de marisma, la manera en que éstas influyen en la distribución de B. halimifolia en las marismas colonizadas, ha sido poco estudiado. Este trabajo tuvo por objetivos identificar las variables hidrodinámicas más importantes que controlan la distribución de esta especie en el estuario de Oyambre (Cantabria, España), para luego usar esta información en la realización de un modelo de hábitat potencial. B. halimifolia se desarrolla en áreas con tiempo inundado (\% al año) que no superan el $26 \%$, salinidades menores a $25 \mathrm{~g} / \mathrm{l}$ y velocidad del agua y caudal circulante menores a $0.1 \mathrm{~m} / \mathrm{s}$ y $0.85 \mathrm{~m}^{3} / \mathrm{s}$ respectivamente. El modelo de hábitat potencial mostró que esta planta no se encuentra representada de forma homogénea en el dominio del estuario, distribuyéndose de forma preferencial en áreas donde los valores medios de las variables hidrodinámicas consideradas son menores a las condiciones hidrodinámicas medias en todo el estuario. La planta también mostró una moderada tolerancia a las condiciones 
hidrodinámicas (Tolerancia «1) teniendo como áreas altamente potenciales de ser habitadas, aquellas con tiempo inundado (\% al año) entre 0 y $21 \%$ y salinidad entre 0-26 g/l. Los cambios en las condiciones hidrodinámicas pueden tener un impacto predecible en el tipo de vegetación y su distribución en marismas. Los resultados sugieren que $\mathrm{B}$. halimifolia se mantendrá en aquellas áreas con reducida influencia mareal, compitiendo con la vegetación nativa.

Palabras clave: Baccharis halimifolia, habitat potencial, condiciones hidrodinámicas, especies invasoras, marismas.

\section{INTRODUCTION}

Coastal estuaries are highly productive systems that combine beaches, dunes and salt marshes (Adam, 2002). Nowadays, several estuaries support a growing human population and a growing number of industries, buildings and tourism facilities. As a consequence, the vegetation and natural structure of the estuaries are receding (Canteras et al., 2003; Heywood \& Iriondo, 2003).

Such anthropic perturbations facilitate the invasion of exotic plants, constituting an extremely difficult problem (Coblentz, 1990). As they are commonly highly opportunistic pioneers, exotic plants can produce large numbers of seeds and can take advantage of the absence of natural enemies. Having a high rate of development, they can colonise modified environments and compete against native plants, changing the appearance, structure and function of the natural plant community. According to GEIB (2006), Baccharis halimifolia (Linneo, 1737) is one of the 20 most dangerous invasive animal and plant exotic invasive species in Spain.

B. halimifolia grows near dunes, fresh and salt-water bodies and deserted areas of Massachusetts, Florida, Arkansas and Texas (USA; Van Deelen, 1991). It was introduced to France in 1863 and to Australia in the 1890s (Caño et al., 2013). It was reported in the Iberian Peninsula in 1941, and was recorded for the first time in Cantabria around 1953. Since then, Oyambre, Noja, and Asón estuaries have been colonised by this species (Campos et al., 2004).

Several studies have analysed the ecology of this plant. Westman et al. (1975) were the first authors to study seed growth under different environmental conditions. Ewe \& Sternberg (2002) studied the seasonal water use of this plant, show- ing that $B$. halimifolia shifted from deep groundwater to shallow soil water in the wet season. In addition, Young et al. (1994) found an average tolerance to brackish soils (between 2 to $5 \mathrm{~g} / \mathrm{L}$ ), being flood level and salt spray other relevant factors for to the distribution of this plant (Tolliver et al., 1997; Griffits, 2006; Zinnert et al., 2012). Environmental factors like water speed, flow and salinity, which are relevant to the distribution of native plant marshes (Crain et al., 2004), might influence the distribution of $B$. halimifolia, but to the best of our knowledge, this effect has not yet been studied for this invasive species.

Exotic species present a threat to the biodiversity, conservation and restoration of many natural areas and often drive ecological changes that may be irreversible. Understanding trends in the spread and density of invasive exotic species, including the impact of control and management activities, is necessary to manage invasive species and should be a vital part of large-scale ecosystemrestoration programs (Doren et al., 2008).

Therefore, the aims of this work were to analyse the influence of the hydrodynamic variables on the distribution of the invasive shrub B. halimifolia in a recently restored estuary and to define the habitat of $B$. halimifolia based on hydrodynamic variables in Oyambre estuary.

\section{MATERIALS AND METHODS}

\section{Study area}

The Oyambre estuary is located in the West of Cantabria (northern Spain) and has two branches, Rabia and Capitán. It is a natural park, is included in the SCI (Site of Community Importance; "Rías Occidentales y Dunas de Oyambre"), has a 


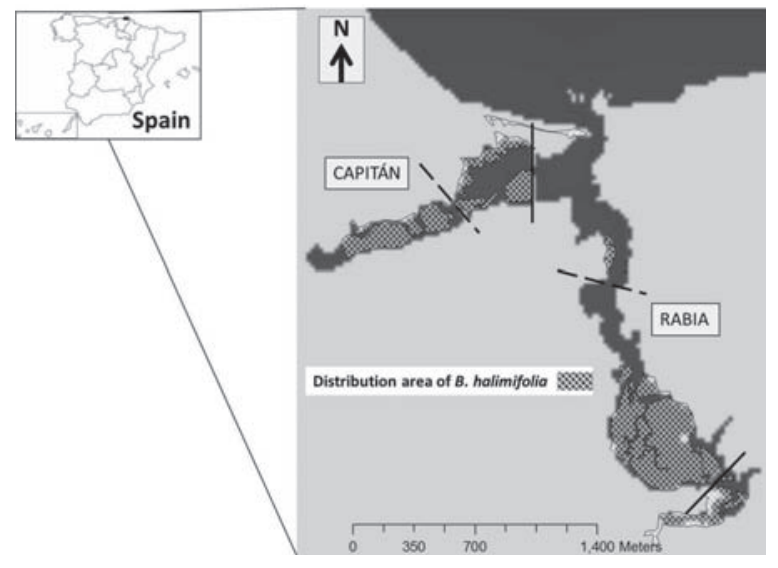

Figure 1. Geographic localisation of Oyambre estuary. Both branches of the estuary (Capitán and Rabia) and the two restoration activities carried out in 2009 are indicated: un-modified roads by continuous lines and open roads by dashed lines. The coverage of B. halimifolia is indicated in the legend. Localización geográfica del estuario de Oyambre. Ambos brazos del estuario (Capitán y Rabia), así como las medidas de restauración realizadas en el año 2009 se encuentran indicadas: caminos sin modificar representados con líneas continuas, caminos modificados con línea discontinua. El área de cobertura de B. halimifolia es indicado en la leyenda.

relative surface of 100 ha, and a perimeter of $13.6 \mathrm{~km}$. Until the first half of 2009, the estuary included four dikes to control the tidal flux, and B. halimifolia was distributed in approximately $35 \%$ of the estuary area, with $>80 \%$ coverage in those areas. In July 2009, the plant was mechanically removed, and in October of the same year, structural modifications were performed on a road that also functioned as a dike for the two estuary branches. This new design allows the natural tidal flux to penetrate the estuary despite the presence of the road (Fig. 1).

Moreover, estuaries on this coast are characterised by large intertidal surfaces and dominated by the tidal dynamic, making them well-mixed. Oyambre is a vertically homogeneous, fluvial fitted valley. It is exposed to a semidiurnal tide, with a mesotidal range varying from $0.5 \mathrm{~m}$ during neap tides to $2.3 \mathrm{~m}$ during spring tides.

\section{Vegetation data}

A distribution map of B. halimifolia in 2011 was developed at a 1:5000 scale using a combination of three aerial photographs. The resulting picture

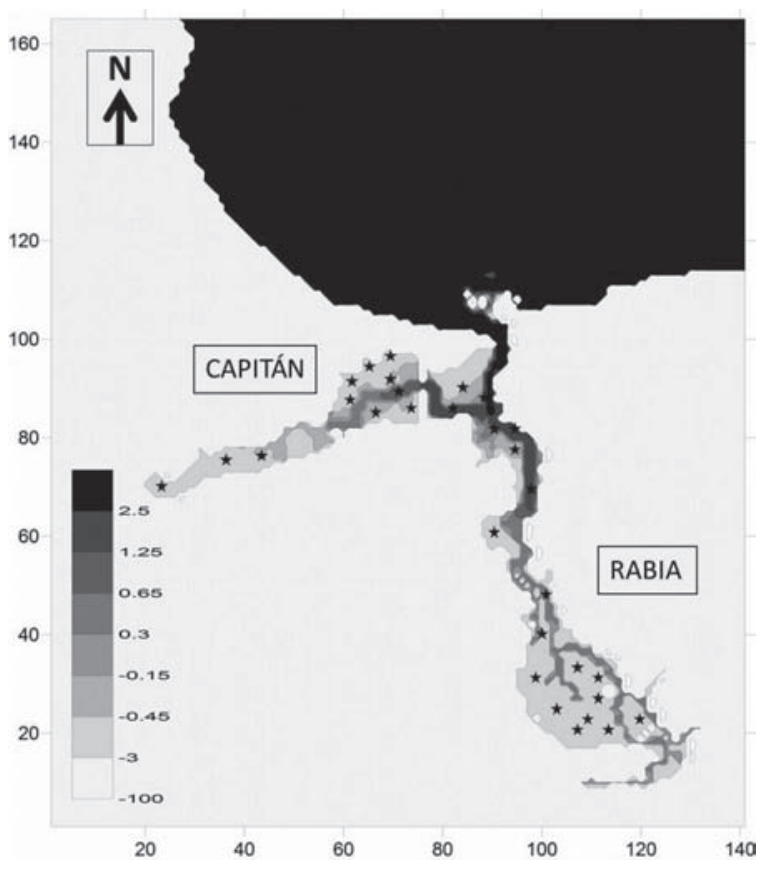

Figure 2. Bathymetric plot of Oyambre estuary. Negative numbers indicate altitudes higher than sea level, with areas marked -100 lying outside the estuaries. Control points, at which numerical modelling data were obtained, are indicated by stars (every single star represents a $25 \times 25 \mathrm{~m}$ cell). Mapa batimétrico del estuario de Oyambre. Los números negativos indican altitudes por encima del nivel del mar, -100 representa áreas por fuera del estuario. Los puntos de control donde se obtuvo información hidrodinámica se encuentran representados con estrellas (cada estrella representa una celda de $25 \times 25$ metros).

was divided into polygons, which were labelled according to a combination of colour and texture to identify the main species of vegetation. To verify these identifications and to determine percent coverage of $B$. halimifolia and other natural salt marsh vegetation, on-the-ground verification was conducted during two later field studies in November. These data were then included in the image data. All versions were created using ArcGis software 9.3 (Cantabria University License, 2011).

\section{Environmental data}

According to the literature (Tolliver et al., 1997; Griffits, 2006; Zinnert et al., 2012), flooding frequency and salinity are the two major variables that control the distribution of $B$. halimifolia. In Oyambre estuary the hydrodynamic regime was 
altered until 2009, yet the natural regime has now been partially restored. Thus, 5 hydrodynamic variables that might affect the development and distribution of $B$. halimifolia were calculated: percent of the year inundated, water flow and water speed, salinity, and freshwater run-off.

Numeric flood modelling was performed with an H2D model, and salinity was modelled with an AD2D model (Bárcena et al., 2011). Both models were performed with the same dike aperture (90 m for Capitán and $100 \mathrm{~m}$ for Rabia) using a bathymetric grid of $25 \times 25 \mathrm{~m}$ and a cell extension of $165 \times 141$. The hydrodynamic modelling was performed to simulate 1 year $(8760$ hours) with a variable-amplitude wave $(2.3 \mathrm{~m}$ maximum altitude); the saline model was performed at $25^{\circ} \mathrm{C}$ and an initial salinity of $35 \mathrm{~g} / \mathrm{L}$. Only the astronomic wave was considered in the simulation.

With velocity, water flow and height of the free surface with respect to the average sea level (ETA) obtained during simulation, the average velocity, average water flow, and average time inundated (time flooded/total time of simulation*100) were estimated at 31 points in the estuary (Fig. 2). Salinity modelling was performed using H2D hydrodynamic data to obtain an average concentration of salt $(\mathrm{g} / \mathrm{L})$ at every point.

Finally, freshwater run-off was estimated using the rational method (Chow et al., 1994). Rainfall intensity was calculated with the Temez (2002) formula, and the average maximum rainfall intensity was obtained using the MAXIM software (De Salas et al., 2005). The water run-off coefficient, necessary for the calculation was taken from the nearest basin (Escudo Basin River, GESHA, 2005). The rational method does not consider the interaction of run-off with different types of soils, evaporation processes and vegetation use, which could affect the volume of water that runs over the basin.

To evaluate the threshold distributions of the plant, percent coverage and hydrodynamic variables in the 31 control points were plotted. With the 5 hydrodynamic variables obtained at the 31 control points, 5 eco-geographical variables (EGVs) in raster format were introduced into the habitat suitability model. Those eco- geographical variables were the result of the interpolation of data for every point in the estuary (the 31 control points), using the inverse distance-weighted method (IDW) in ArcGis 9.3. IDW interpolation is based on the assumption that objects that are close to one another are more alike than those that are farther apart. To predict a value for any unmeasured location, IDW uses the measured values from surrounding locations. Values from closer locations have more influence on the predicted value than those from locations farther away. Thus, IDW assumes that each measured point has a local influence that diminishes with distance.

\section{Habitat-suitability model}

The ecological niche factor analysis (ENFA) developed by Hirzel et al. (2002) computes suitability functions by examining the species distribution across eco-geographical variable space. This approach determines the relationships between variables and establishes combinations of these variables to produce uncorrelated factors (Valle et al., 2011). The first factor is defined as the 'marginality' (M) of the species niche, which is the absolute difference between the global mean (the mean of the variable throughout the study area; Bryan \& Metaxas, 2007) and the species mean (the mean of a variable when the species is present) for each environmental variable (Hirzel et al., 2002) and is calculated as

$$
m_{i}=\frac{\left|m_{G i}-m_{S i}\right|}{1.96 \sigma_{G i}}
$$

where $m_{i}$ is the marginality of a particular environmental variable, $m_{G i}$ is the global mean of the variable, $m_{S i}$ is the mean of the variable in the species range, and $\sigma_{G i}$ is the standard deviation of the global distribution of the variable (Bryan \& Metaxas, 2007).

Combining the $m_{i}$ of individual environmental variables, ENFA computes an overall global M; Hirzel et al., 2002; Reutter et al., 2003). M ranges between 0 and 1, with larger values indicating that the species is not equally distributed throughout the environment. 
Specialisation (S) is the second factor and indicates how restricted the species niche is in relation to the study area ('global' area). It is defined as the ratio of variance in the global distribution to variance in the species distribution of the environmental variable (Hirzel et al., 2002; Reutter et al., 2003), and it is calculated as

$$
\lambda_{i}=\sigma_{G i} / \sigma_{S i}
$$

where $\lambda_{i}$ is the $\mathrm{S}$ for a particular environmental variable and $\sigma_{G i}$ and $\sigma_{S i}$ are the species and global standard deviations of the variable, respectively. As for M, S for individual environmental variables is combined to compute an overall global S. S ranges from 1 to N, with the niche becoming narrower as $\mathrm{S}$ increases. Tolerance $(\mathrm{T})$, which is the inverse of $\mathrm{S}$, ranges from 0 to 1 and represents the general tolerance of the species to environmental conditions. Values near 1 indicate a higher tolerance to natural conditions.

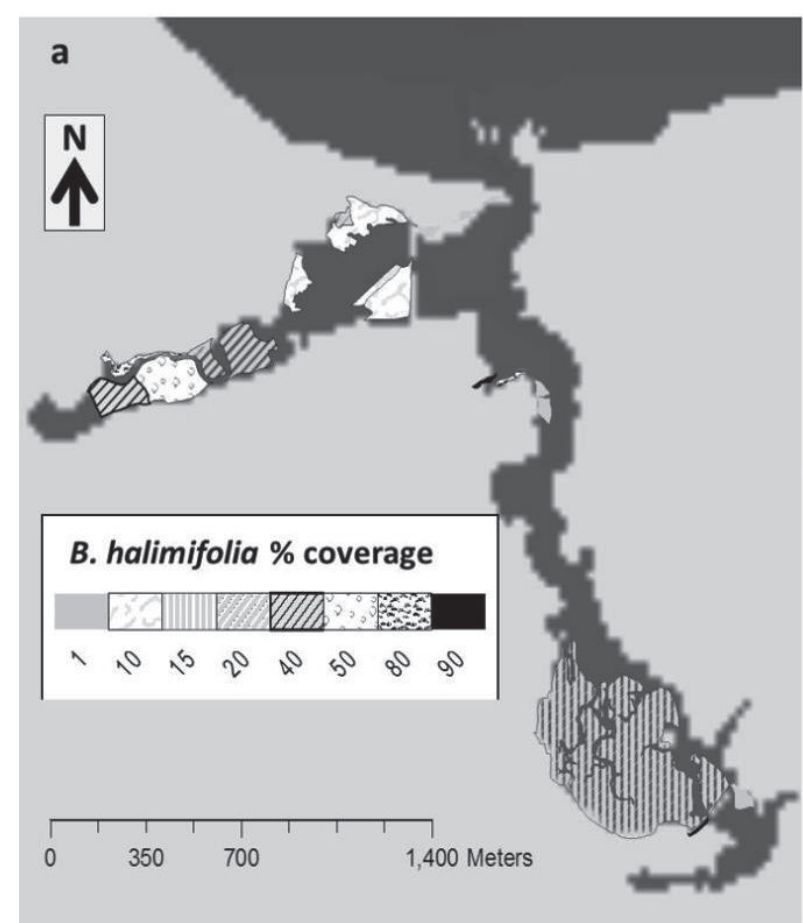

Marginality, specialisation and tolerance for the whole estuary were obtained as results of the ENFA model. The total variance of the B. halimifolia distribution was derived from the combination of all eco-geographical variables (EGVs). For M, EGVs are sorted by decreasing the absolute value of coefficients. Positive values indicate that the species prefers locations with higher values on the corresponding EGV than average in the study area, and vice versa. Coeficient signs have no relevance on the specialisation factors (e.g., specialisation 1, 2, 3). The sum of the factors (marginality and specialisation) explains $100 \%$ of the total variance in the distribution of the plant.

For the habitat suitability model, B. halimifolia distribution data and environmental data (mean water speed, mean water flow, percent of the year inundated, salinity and water run-off) from 2011, were fed into BioMapper 4.0 software (www.unil.ch/biomapper/) as a raster-based grid file (eco-geographical variables), with a

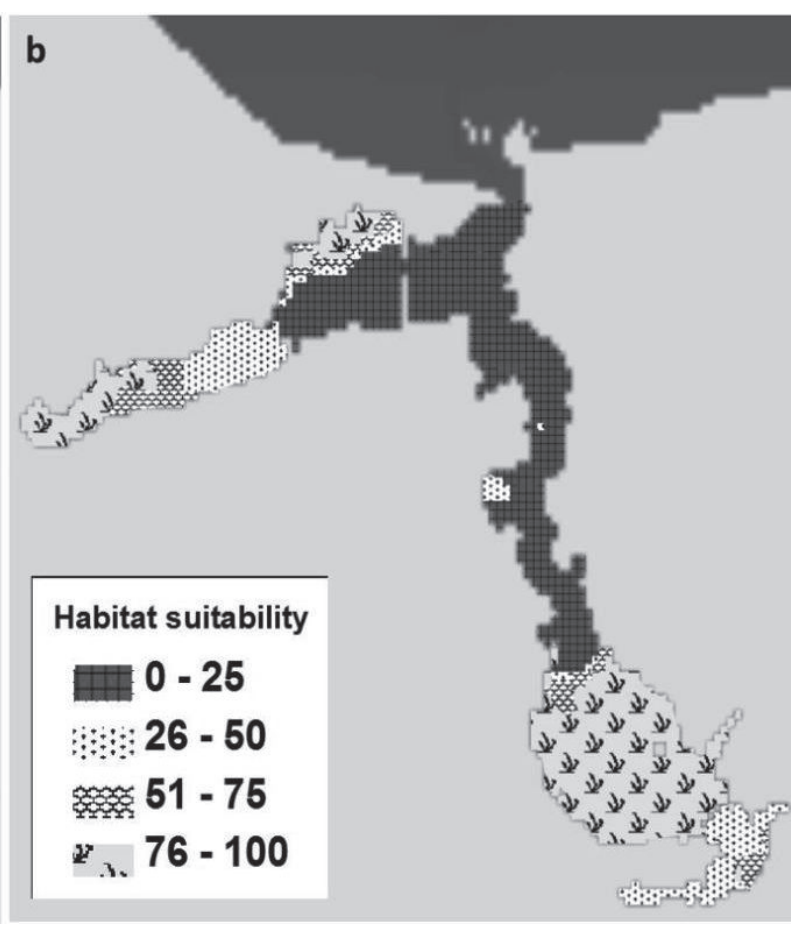

Figure 3. (a) B. halimifolia coverage in November 2011, Oyambre estuary domains. The coverage values, as adjusted after field verification, are indicated on the left-hand side of the figure. (b) Habitat suitability map for 2011. Accuracy levels are indicated for the whole estuary. (a) \% de cobertura de B. halimifolia en Noviembre 2011 dentro de los dominios del estuario de Oyambre. Los diferentes valores de \% de cobertura, ajustados en campo se encuentran indicados en la porción izquierda de la figura. (b) Mapa de hábitat potencial para el año 2011. Los niveles de potencialidad de hábitat se encuentran calculados para toda la superficie del estuario. 
horizontal resolution of $25 \times 25 \mathrm{~m}$ and the same extent. Subsequently, a box-cox algorithm was applied to normalise all eco-geographical variables. The habitat suitability map was produced using a global $\mathrm{M}$ value (0 to 100) for all environmental factors in each cell that indicates the most probable distribution of the plant according to the real distribution and eco-geographical variables in the model.

The habitat suitability map was rescaled using the isopleth method and the validation of the model was done by the Boyce Index (Boyce et al., 2002), which indicates a good adjustment of the prediction when the index value is $>0.7$. Finally, the ENFA results were plotted using the average algorithm. This algorithm assumes that the mean value for the environmental variable within the species distribution is approximately the same as the value in the study area (Hirzel et al., 2002; Hirzel \& Arletta, 2003).

\section{RESULTS}

\section{Plant pattern distribution}

In 2011, B. halimifolia was present in $31 \%$ of the total area of the estuary, representing $33.49 \%$ of the Rabia surface and $46.66 \%$ of the Capitán surface. Where the species was present, coverage was between 1 and $90 \%$. In Capitán, where the flood restoration was less important, the plant had coverage between 10 and $80 \%$. In contrast, in Rabia, where flood restoration was more significant (see Fig. 1), coverage was between 1 and $15 \%$ (Fig. 3a). The coverage differences between branches were statistically significant (Mann-Whitney test, $Z=-2.052, \rho=0.040$ ). Analyses of salt-marsh vegetation showed that the principal area of distribution of $B$. halimifolia in Rabia was dominated by Juncus maritimus (Lamarck, 1789) (average $78 \%$ ). In Capitán, those areas were dominated by Halimione portulacoides (Aellen, 1938) (average $65 \%$ ).

$B$. halimifolia presented a threshold distribution pattern, showing greater coverage in areas that are inundated $<20 \%$ of the year. The plant did not invade areas that are inundated $>26 \%$ of the year (Fig. 4a), and was distributed in areas where water speed and water flow were $<0.1 \mathrm{~m} / \mathrm{s}$ and $<0.85 \mathrm{~m}^{3} / \mathrm{s}$, respectively (Fig. $4 \mathrm{~b}$ and Fig. 4c). Furthermore, B. halimifolia grew in areas where the median salinity was $<25 \mathrm{~g} / \mathrm{L}$ (Fig. 4d), but did not show a specific threshold distribution in terms of run-off (Fig. 4e).

\section{Habitat suitability model}

Marginality (M) was 0.57 , global specialisation (S) was 2.22 , and global tolerance $(\mathrm{T})$ was 0.45 . M indicates that the estuary presents a combination of average hydrodynamic conditions that differ from the average hydrodynamic conditions preferred by the plant. $\mathrm{S}$ ranged between 0 and $\mathrm{N}$ and in combination with $\mathrm{T}(1 / \mathrm{S})$ indicates that the plant is restricted in its distribution area. With 4 ecogeographical factors, the ENFA model explained $96.4 \%$ of the total variability, with the first factor (marginality) covering $54.4 \%$ of the explained variability. Factor 2 (specialisation 1) explained $18.6 \%$, Factor 3 (specialisation 2) $10.6 \%$ and Factor 4 (Specialisation 3) $7.8 \%$ (Table 1).

Table 1. Variance explained by the first four ecological factors (out of 5) and coefficient values for the 5 eco-geographical variables $($ EGVs) used. Key: Wat. fl.= water flow; Wat. sp. = water speed; T. in. $\%=$ percent of the year inundated; Saln. = salinity. Varianza explicada por los primeros cuatro factores ecológicos (de un total de 5) con los coeficientes obtenidos para cada una de las variables eco-geográficas $(E G V s)$. Abreviaturas: Wat. fl. = caudal; Wat. sp. = velocidad; . in. \% = tiempo inundado $(\%$ a al año); Saln. = salinidad.

\begin{tabular}{cccc}
\hline Marginality (59.4 \%) & Spec. 1 (18.6 \%) & Spec. 2 (10.6 \%) & Spec. 3 (7.8 \%) \\
\hline Wat. fl. (-0.529) & T. in. \% (0.807) & Wat. sp. (0.834) & Wat. fl. (-0.74) \\
Run-off (0.524) & Saln. (-0.545) & T. in. \% (-0.425) & Wat. sp. (0.586) \\
Wat. sp. (-0.422) & Run-off (0.157) & Wat. fl. (-0.255) & Run-off (-0.315) \\
T. in. \% (-0.378) & Wat. fl. (-0.135) & Run-off (0.199) & Saln. (-0.091) \\
Saln. (-0.353) & Wat. sp. (0.098) & Saln. (0.136) $\%(0.03)$ \\
\hline
\end{tabular}


The most important (highest $\mathrm{M}$ values) variables controlling the presence of $B$. halimifolia were water flow $(-0.53)$, run-off $(0.52)$ and water speed $(-0.42)$. The model showed that this plant prefers areas where the average water flow and water speed are lower than the values obtained for the whole estuary and areas where the water run-off is higher than in the estuary overall. $B$. halimifolia also showed specialisation in terms of percent of the year inundated (0.80) and salinity
(0.54) in the Specialisation factor 1 (which explained $18.6 \%$ of the total variance). In Specialisation 2, which explained $10.6 \%$ of the total variance, water speed $(0.84)$ had the greatest value. In Specialisation 3 (which explained $7.8 \%$ of total variance), water flow $(-0.74)$ was the variable with the greatest absolute value. These statistics indicate that percent of the year inundated and salinity in particular limit the range of $B$. halimifolia in the estuary. Water speed and water flow
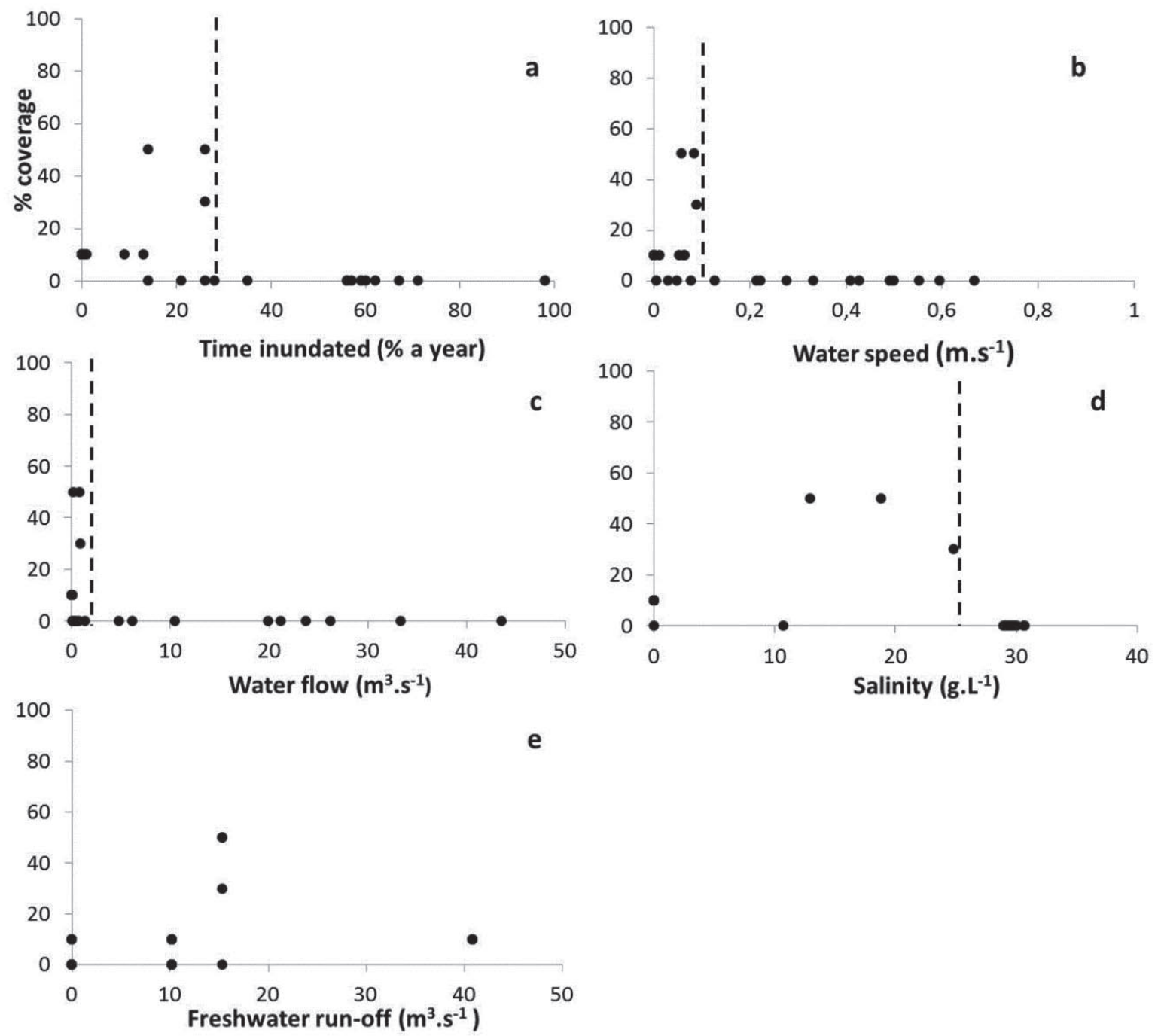

Figure 4. Coverage and distribution of B. halimifolia with respect to time inundated (a), water speed (b), water flow (c), salt concentration (d) and freshwater run-off (e). Dashed lines indicate the distribution limits of the plant in Oyambre for every parameter. Valores de porcentaje de cobertura y distribución de $\mathrm{B}$. halimifolia respecto del tiempo inundado (\% al año) (a), velocidad del agua (b), caudal (c), concentración salina (d) y escorrentía superficial (e). La línea de puntos indica el límite de distribución de la planta en el estuario de Oyambre para cada uno de los parámetros analizados. 
are secondary control variables according to the ENFA model.

The results of the cross-validation performed to evaluate model quality were indicative of its high predictive capacity (Boyce index: $0.79 \pm$ 0.18 ), and allowed us to generate an habitat suitability map with ranges between 0 and 100 . This map was divided into 4 intervals of suitability: from 0 to 25 (unsuitable); from 25 to 50 (scarcely suitable); from 50 to 75 (moderately suitable); and from 75 to 100 (highly suitable; Fig. 3b). These habitat suitability intervals occupy $45 \%$, $14 \%, 7 \%$ and $34 \%$ of the estuary, respectively.

The highly suitable area (from 70 to 100) represents the most probable distribution of the plant, indicating a limited range of distribution of $B$. halimifolia in terms of percent of the year inundated (between 0 and $21 \%$ ) and water speed $(0-0.08 \mathrm{~m} / \mathrm{s})$ but a large range distribution in terms of salinity $(0-26 \mathrm{~g} / \mathrm{L})$, water flow $\left(0-2.31 \mathrm{~m}^{3} / \mathrm{s}\right)$ and run-off $\left(0-41 \mathrm{~m}^{3} / \mathrm{s}\right)$.

To simplify the analysis, those four categories of suitability were grouped into unsuitable areas (from 0 to 49) and suitable areas (from 50 to 100). Specifically, $41 \%$ of the total area of the estuary (41 ha) was recognised by the habitat model as suitable for the growth of B. halimifolia, and $59 \%$ of the estuary (59 ha) was unsuitable, lacking the necessary conditions for the growth of the plant. The results also indicated that those unsuitable areas corresponded to depths between $0.40 \mathrm{~m}$ above sea level and $2.52 \mathrm{~m}$ below sea level, and were associated with flood frequencies greater than $28 \%$ a year (Fig. 5).

\section{DISCUSSION}

\section{Plant pattern distribution}

Salt marshes are dynamic, transitional systems between freshwater and marine environments that respond to environmental changes (Adam, 2002). The Oyambre estuary has been colonised by $B$. halimifolia, an introduced exotic plant, which was mechanically removed in 2009, with the modification of the C-6316 road. This measure allowed greater movement of the tides in the estuary to penetrate deeper than before restoration. However, in 2011 the population

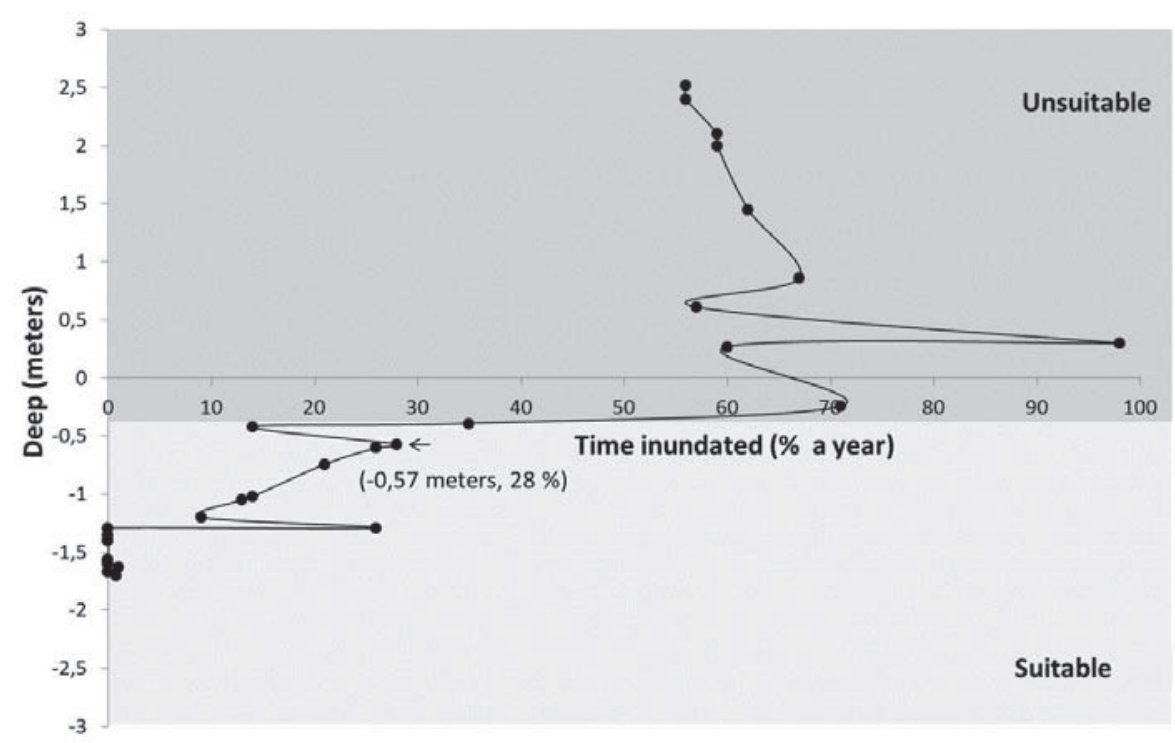

Figure 5. Estimated time inundated (\% of the year) at different depths in the estuary. Coloured areas represent zones where the habitat suitability model showed two major groups (Suitable/Unsuitable). Negative values represent points above sea level. Tiempo total inundado (\% al año) estimado para diferentes profundidades del estuario. Las áreas coloreadas indican los dos grandes grupos indicados por el modelo de hábitat potencial (Adecuado-No adecuado). Valores negativos representan puntos ubicados por encima del nivel del mar. 
was recovered, and our results indicate that the distribution of $B$. halimifolia is controlled by flooding, and this plant will remain in those areas where the influence of flooding is reduced.

In Rabia, coverage was between 1 and $15 \%$; and on the other hand, in Capitán where tidal restoration was less significant (as another dike still controls the tidal flow) coverage was between 10 and $50 \%$. These results suggest a greater effect of the natural tidal regime of the estuary in those areas where the seawater penetrates deeper. Espinar (2009) claimed that any modification to soil salinity, inundation patterns or drainage processes might alter vegetation communities in salt marshes. In this particular case, the restoration of the tidal cycle into the estuary seems to be an important stressor for B. halimifolia. When the estuary recovered part of its natural tidal cycle, the areas that were dominated by $B$. halimifolia in 2009, were re-colonised by native vegetation in 2011. J. maritimus and $H$. portulacoides, species that correspond to the high and middle salt-marsh zonation, are now dominant species in many areas where $B$. halimifolia is present. The ability of plant species to tolerate environmental stress is especially important in coastal and riverine wetlands, where gradients in hydrology or salinity determine dominant vegetation patterns (Poulter et al., 2008). In Oyambre estuary, the increased tidal influence is changing plant distribution patterns, allowing the recovery of native salt marsh vegetation. This finding is consistent with Cano et al. (2013), who indicated that in other estuaries of the Cantabrian Sea, B. halimifolia is distributed in areas where flooding is reduced and salinity is moderate. Our results are also consistent with those found on other restored estuaries (e.g., salt marshes from the Baltic Sea), where five years after removing the dike line, nearly $75 \%$ of 350 ha were covered by typical salt marsh and salt grassland vegetation types (Bernhardt \& Koch, 2003).

Pino et al. (2006) indicated that in a highly saline habitat, environmental conditions limit the number, coverage and distribution of alien species, but in less saline environments with a reduced tidal influence, alien species are favoured. After dike modifications in Oyambre estuary, the hydrodynamic conditions changed, and the results obtained here show that percent of the year inundated, water speed, water flow and salinity control the distribution and coverage of $B$. halimifolia.

This plant was distributed in areas that are inundated $<26 \%$ of the year. Tolliver et al. (1997) demonstrated that exposure to saline water for longer than 30 consecutive days causes necrosis in this plant. Our results indicate that $B$. halimifolia can resist flood exposure for a mean of 94 days of immersion per year, for 6 to 10 hours a day. Moreover, water speed and flow showed similar trends indicating that in Oyambre estuary, B. halimifolia is distributed in areas where the water speed is $<0.1 \mathrm{~m} / \mathrm{s}$ and flow is $<0.85 \mathrm{~m}^{3} / \mathrm{s}$. Water flow and water speed are highly linked, yet they supply different ecological information in terms of their effects on plant morphology. To the best of our knowledge, no studies have reported the relevance of water flow and water speed to the distribution of B. halimifolia. In a more general context water movement over a surface can be associated with soil erosion and break and deflocculation of clays with effects on soil stability and thus on vegetation in marshes (Kozlowski, 1997).

Regarding salinity, Zinnert et al. (2012) established that $B$. halimifolia can resist high salt concentrations in its tissues (>300 mM), maintaining a low photosynthetic activity without necrosis, and Tolliver et al. (1997) showed that this plant can resist concentrations of $20 \mathrm{~g} / \mathrm{L}$ without mortality. In Oyambre estuary, we found that $B$. halmifolia can resist areas where salinity is below $25 \mathrm{~g} / \mathrm{L}$.

\section{Habitat suitability model}

Knowledge of the threshold distribution of invasive species can contribute to the understanding of the factors that control their distributions; however, prediction of the distribution of alien plants is difficult, as invasions are unpredictable and complex (Townsend-Peterson \& Vieglais, 2001). One solution was proposed by Ward (2007), who explained that the study of habitat can be an important tool in understanding and 
managing invasions. In this respect, habitat suitability model (ENFA) showed that B. halimifolia would not be equally distributed throughout the estuary, being restricted in its distribution by the hydrodynamic regime. The estuary does not present the optimum niche combination $(\mathrm{M}<1)$, but the plant's tolerance allows it to persist in Oyambre $(\mathrm{T}=0.45)$; especially, in elevated areas $(>0.4 \mathrm{~m})$ where the tidal influence is reduced. These results are consistent with Caño et al. (2013) who have indicated that thresholds values of salinity and waterlogging limit the survival and spread of $B$. halimifolia in a halophilous community.

In addition, ENFA model showed that B. halimifolia tend to grow in those areas where water speeds is between $0-0.08 \mathrm{~m} / \mathrm{s}$ (mean, $0.01 \mathrm{~m} / \mathrm{s}$ ) and water flows is between $0-2.31 \mathrm{~m}^{3} / \mathrm{s}$ (mean, $0.18 \mathrm{~m}^{3} / \mathrm{s}$ ). Conversely, $B$. halimifolia has moderate tolerance to variations in time inundated and salinity, preferring areas with low tidal influence $(<28 \%)$, having a considerable tolerance to salinity (0-26 g/L). The ENFA model also showed that the plant could be favoured by freshwater run-off; nevertheless, freshwater contributed by run-off to the areas surrounding the estuary is absorbed into the soil, by vegetation or evaporates (Chow et al., 1994). This dynamic was not considered in the habitat model; therefore, the influence of freshwater may have been overestimated in the habitat suitability model.

Regarding eradication methods of the plant, many strategies have been used, such as the introduction of natural enemies, which depends on factors like size of the plant, density, distribution, phenotype, and associated microclimate (Bolt \& White, 1992; Charudattan, 2001; Sims-Chilton et al., 2009, Altfeld \& Stiling, 2009). Another common measure is the use of controlled fire (Owens et al., 2007), being demonstrated that the growth of B. halimifolia is favoured (Grace, 2002). In this study, our results suggest that tidal restoration could represent a good passive strategy for the control of $B$. halimifolia in tidal estuaries modified by dikes, which in combination with mechanical removal of the plant could be used to avoid germination of new individuals and recovery of older plants.

\section{CONCLUSIONS}

Hydrodynamic regime is an important predictor of B. halimifolia distribution in Oyambre estuary, showing that this plant is restricted in its distribution by time inundated and salinity. These results also showed that changes in hydrodynamic conditions may have a predictable impact on the type and distribution of vegetation in salt marshes. $B$. halimifolia will remain in areas where the tidal influence is reduced, most likely competing with vegetation that is better adapted to the new conditions in the estuary.

\section{ACKNOWLEDGMENTS}

We especially thank María Recio, Javier Bárcena and Gorka Bidegain from the IH Cantabria Institute for their cooperation in the field studies, numerical modelling of environmental variables and execution of the habitat suitability model, respectively. We also wish to thank Mercedes Marchese, who read this manuscript and improved it with her comments.

\section{REFERENCES}

ADAM, P. 2002. Saltmarshes in a time of change. Environmental Conservation, 29: 39-61

ALTFELD, L. \& P. STILING. 2009. Effects of aphid-tending Argentine ants, nitrogen enrichment and early-season herbivory on insects hosted by a coastal shrub. Biological Invasion, 11: 183-191.

BÁRCENA, J. F., A. GARCÍA, A. G. GÓMEZ, C. ÁlVAREZ, J. A. JUANES \& J. A. REVILLA. 2011. Spatial and temporal flushing time approach in estuaries influenced by river and tide. An application in Suances Estuary (Northern Spain). Estuarine, Coastal Shelf Science, 112: 40-51.

BERNHARDT, K. \& M. KOCH. 2003. Restoration of a salt marsh system: temporal change of plant species diversity and composition. Basic and Apply Ecology, 4: 441-45.

BOLT, P. E. \& R. E. WHITE. 1992. Life history and larval description of Exema elliptica karren (Coleoptera: Chrysomelidae) on Baccharis halimifolia L. (Asteraceae) in Texas. Proceeding of the entomological society of Washington, 94: 83-90. 
BOYCE, M. S., P. R. VERNIER, S. E. NIELSEN \& F. K. A. SCHMIEGELOW. 2002. Evaluating resource selection functions. Ecological Modeling, 157: 281-300.

BRYAN, T. L. \& A. METAXAS. 2007. Predicting suitable habitat for deep-water gorgonian corals on the Atlantic and Pacific Continental Margins of North America. Marine Ecology Progress Series, 330:113-126.

CAMPOS, J. A., M. HERRERA, I. BIURRUN \& J. LIOIDI.. 2004. The role of alien plants in the natural coastal vegetation in central-northern Spain. Biodiversity Conservation, 13: 2275-2293.

CANTERAS, J. C, S. LÓPEZ LIÑEIRO \& J. P. LLEDÍAS. 2003. Anthropic pressure on the Cantabrian coast. J,ournal of Marine Research, 1: 65-84.

CAÑO, L., CAMPOS J. A., GARCÍA MAGRO D., HERRERA M. 2013. Replacement of estuarine communities by an exotic shrub: distribution and invasion history of Baccharis halimifolia in Europe. Biological Invasions, 15: 1183-1188.

CHARUDATTAN, R. 2001. Biological control of weeds by means of plant pathogens: Significance for integrated weed management in modern agro-ecology. BioControl, 46: 229-260.

CHOW, V., D. MAIDMENT \& L. MAYD. 1994. Hidrología Aplicada. McGraw-Hill Interamericana S.A., Santa Fe de Bogotá, Colombia.

COBLENTZ, B. E. 1990. Exotic organisms. A dilemma for conservation biology. Conservation $\mathrm{Bi}$ ology, 4: 261-265.

CRAIN, C. M, S. M. SILLIMAN, S. L. BERTNESS, M. D. BERTNESS \& S. L. BERTNESS. 2003. Physical and biotic drivers of plant distribution across estuarine salinity gradients. Ecology, 85: 2539-2549.

DE SALAS REGALADO, L., L. CARRERO DIÉZ \& J. A. FERNÁNDEZ YUSTE. 2005. MAXIN: Aplicación SIG para la estimación de valores Intensidad-Duración-Frecuencia de precipitaciones en la España peninsular. Ingeniería Civil, 146: 137-143.

DOREN, R. F., J. C. VOLIN \& J. H. RICHARDS. 2008. Invasive exotic plant indicators for ecosystem restoration: An example from the Everglades restoration program. Ecological Indicators, 9: 2936.

ESPINAR, J. L. 2009. 1330. Pastizales salinos atlánticos (Glauco-Puccinellietalia maritimae). En: Bases ecológicas preliminares para la conserva- ción de los tipos de hábitat de interés comunitario en España. Prenda Marin J. C. (ed.). Madrid, España.

EWE, S., M. \& S. L. STERNBERG. 2002. Seasonal water-use by the invasive exotic, Schinus terebinthifolius, in native and disturbed communities. Oecologia, 133: 441-448.

GEIB. 2006. TOP 20: Las 20 especies exóticas invasoras más dañinas presentes en España. Capdevila-Argüelles L., B. Zilletti (eds.), GEIB, Serie Técnica N. 2, León, España.

GESHA. 2005. Estudio de los recursos hídricos de los ríos de la vertiente norte de Cantabria. Grupo de Emisarios Submarinos e Hidráulica Ambiental, Universidad de Cantabria, Santander.

GRACE, J. B., M. D. SMITH, S. L. GRACE, S. L. COLLINS \& T. J. STOHLGREN. 2001. Interactions between fire and invasive plants in temperate grasslands of North America. In: Proceedings of the invasive species workshop: the role of fire in the control and spread of invasive species. Galley K. E. M., T. P. Wilson (eds.): 40-65. Tall Timbers Research Station, Tallahassee, Florida.

GRIFFITS, M. E. 2006. Salt spray and edaphic factors maintain dwarf stature and community composition in coastal sandplain heathlands. Plant Ecology, 186: 69-86.

HEYWOOD, V. H. \& J. M. IRIONDO. 2003. Plant conservation: old problems, new perspectives. $B i$ ological Conservation, 113: 321-335.

HIRZEL, A. H., J. HAUSSER, D. CHESSEL \& N. PERRIN. 2002. Ecological-niche factor analysis: how to compute habitat-suitability maps without absence data? Ecology, 83: 2027-2036.

HIRZEL, A. H. \& R. ARLETTA. 2003. Modelling habitat suitability for complex species distributions by environmental-distance geometric mean. Environmental Management, 32: 614-623.

KOZLOWSKI, T. T. 1997. Responses of woody plants to flooding and salinity. Tree Physiology Monographies, 1: 1-29.

OWENS, A. E, C. E. PROFFITT \& J. B. GRACE. 2007. Prescribed fire and cutting as tools for reducing woody plant succession in a created salt marsh. Wetlands Ecology and Management, 15: 405-416.

PINO, J., J. M. SEGUI \& N. ÁLVAREZ. 2006. Invasibility of Four Plant Communities in the Llobregat Delta (Catalonia, NE of Spain) in Relation to their historical stability. Hydrobiologia, 570: 257-263.

POULTER, B., N. L. CHRISTENSEN \& S. S. QIAN. 2008. Tolerance of Pinus taeda and Pinus serotina 
to low salinity and flooding: Implications for equilibrium vegetation dynamics. Journal of Vegetation Science, 19: 15-22.

REUTTER, B. A., V. HELFER, A. H. HIRZEL \& P. VOGEL. 2003. Modelling habitat-suitability using museum collections: an example with three sympatric Apodemus species from the Alps. Journal of Biogeography, 30: 581-590.

SIMS-CHILTON, N. M, M.P. ZALICKI \& I. M. BUCKLEY. 2010. Long term climate effects are confounded with the biological control programme against the invasive weed Baccharis halimifolia in Australia. Biological Invasions, 12: 3145-3155.

TEMEZ, J. R. 2002. Generalización y mejora del método racional. Versión Dirección General de Carreteras de España. Ingeniería Civil, 82: 51-56.

TOLLIVER, K. S, D. W. MARTIN, D. R. YOUNG. 1997. Freshwater and saltwater flooding response for woody species common to barrier island swales. Wetlands, 17: 10-18.

TOWNSEND-PETERSON, A. \& D. A. VIEGLAIS. 2001. Predicting species invasions using ecological niche modeling: new approaches from bioinformatics attack a pressing problem. BioScience, 51: 363-371.

VALLE, M., A. BORJA, G. CHUST, I. GALPAR-
SORO \& J. M. GARMENDIA. 2001. Modelling suitable estuarine habitats for Zostera noltii, using Ecological Niche Factor Analysis and Bathymetric LiDAR. Estuarine, Coastal Shelf Science, 94: 144-154.

VAN DEELEN, T. R. 1991. Baccharis halimifolia. In: Fire Effects Information System. U.S. Department of Agriculture, Forest Service http://www. fs.fed.us/database/feis/. Acceded on September 12 of 2012.

WARD, D. 2007. Modelling the potential geographic distribution of invasive ant species in New Zealand. Biological Invations, 9: 723-735.

WESTMAN, W. E., F. D. PANETTA \& T. D. STANELY. 1975. Ecological studies on reproduction and establishment of the woody weed, groundsel bush (Baccharis halimifolia L.: Asteraceae). Australian Journal of Agricultural Research, 26: 855870.

YOUNG, D. R., D. L. ERICKSON \& S. W. SEMONES. 1994. Salinity and the small-scale distribution of three barrier island shrubs. Canadian Journal of Botany, 72: 1365-1372.

ZINNERT, J. C., J. D. NELSON \& A. M. HOFFMAN. 2012. Effects of salinity on physiological responses and the photochemical reflectance index in two co-occurring coastal shrubs. Plant Soil, 1: 1-11. 